\title{
The Story of our Experiments with London: The Victorian City in Indian Imagination (1870-1900)
}

\author{
Arup K. Chatterjee \\ Associate Professor, OP Jindal Global University, ORCID: oooo-ooo1-8880-7762. \\ Email: arupkchatterjee@jgu.edu.in
}

\begin{abstract}
This paper argues for a hermeneutic shift in interpreting accounts of Victorian London in Indian travelogues written between 1870 and 1900, taking the founding of the Indian National Congress (1885) and the climate of anticolonial agitation as a political fulcrum for a new aesthetic drive in the ways in which the imperial capital was imagined as a new psychogeography by its colonial subjects. Drawing on travelogues by Pothum Ragaviah, Trailokyanath Mukharji, Behramji Malabari, Lala Baijnath, T.B. Pandian and G.P. Pillai, I outline how London was reinvented in the Indian imagination as a typographical experiment in pictograms and audiograms. The urban, domestic and atmospheric phenomena of the metropolis was recreated as archetypes in the colonized mind of the reader back home, as a new model of modernity, a new way of typographic expertise over the imperial capital, and a therapeutic means of overcoming the ongoing traumas of colonization. Pictograms of its intimate domestic quarters and atmospheric nuances or audiograms of its majestic choirs and ambient traffic noise, London's phenomenology was brought alive in the Indian consciousness through these travelogues, which besides playing a literary role also politically empowered the colonized imagination for the wish-fulfilment of an autonomous geography. Seen in the light of the great morphological transformations in places like East Ham, Wembley, Southall or Brick Lane-those parts of present-day London with heavy concentrations of South Asians-late Victorian Indian accounts of the city and their typographical experiments were the early "ethno-scapes" and "kaleido-scapes" for the colonized imagination to inhabit the imperial capital in a psychogeographical capacity, much before South Asian immigrations since the 1950 .
\end{abstract}

Keywords: Victorian London; Gandhi; Ragaviah; Malabari; Mukharji; Baijnath; Pandian; Pillai

Nearly 6o,00o books written on the Orient between 1800 and 1950 by a battalion of European ambassadors, diplomats, travellers, scholars, historians, anthropologists, collectors, army-men and memsahibs, embedded the contours of Middle-Eastern and South Asian colonies in Western imagination. Victor Kiernan and Edward Said, two of the most prominent early critics of Orientalism in postcolonial times, called it a "collective daydream," a "mythology of the mysterious East" and "notions of Asian inscrutability" (Kiernan, 1969, p. 131; Said, 1979, p. 52).

One of the dangers of sustained critiques of European Orientalism, that Daniel Martin Varisco identifies, is the unprecedentedly indiscriminate use of from Said's work to prove how Orientalist texts were totally "incapable of escaping the latent bias inherent" in the larger imperial discourse, therefore fallaciously assuming what ought to be proven, and which texts are amenable to the evidence to prove it with $(1979$, p. 9; 44; 104). Another danger-most relevant to this paper-is that the constriction of the field of intellectual thinking around writings by Orientals themselves that shaped new discourses of the Occident. Orientalism, at its fag end, saw fragments of the Occident-in fragments of London's atmosphere and phenomenology-lurking in the

(c) AesthetixMS 2020. This Open Access article is published under a Creative Commons Attribution Non-Commercial 4.o International License (http://creativecommons.org/licenses/by-nc/4.o/), which permits non-commercial re-use, distribution, and reproduction in any medium, provided the original work is properly cited. For citation use the DOI. For commercial re-use, please contact editor@rupkatha.com. 
Indian imagination of Europe. With due credit to Said, a formidable group of historians has come to the forefront with accounts of Indians based in, or travelling to, England and London, since the 1600s (Visram, 2002; Fisher, 2006; Nasta, 2013; Sen, 2005; Lahiri, 2013).

If the English Education Act of 1835 saw colonial rule strengthen its fangs on Indian, it also coincided with the beginning of several influential Indians arriving in London from where to cause a dent in Orientalism. Raja Rammohun Roy, Ardaseer Cursetjee Wadia, Dwarkanath Tagore, Keshub Chandra Sen, and a whole new fraternity of civil service aspirants and legal scholars made London the destination for India's social emancipation, in the nineteenth-century. If the founding of the Indian National Congress in 1885 was a watershed moment in Indian democracy, much of the agitation that led to it and its subsequent activism had its roots in London. W.C. Bonnerjee, the first President of the Congress was the well-known proprietor of the Indian-styled Victorian mansion called Kidderpore, in Croydon, what was then in suburban London. By the 1890 s, Dadabhai Naoroji and Muncherji Bhownaggree became the first Indians to sit at the House of Commons, while Romesh Chunder Dutt worked in close quarters on the joint project of intellectually and politically decolonizing the Indian mind.

Victorian London saw tens of thousands of Indian lascars dotting the dockyards around Tilbury and West India Docks; the coming up of Home for Indian and South Asian ayahs, founded by the Rogers family and later revived by the missionary Joseph Salter; lavish Indian artefacts like Oriental carpets, porcelain and chinaware, and jade hookahs strewn about the East India House or later the India Office; and Indian commodities like curry powder, tea and opium becoming popular items as culinary, medicinal or narcotic ingredients. London had also witnessed extravaganzas of Eastern spectacles in the Crystal Palace Exhibition (1851), where the prime exhibit was the Kohinoor diamond extracted from the eleven-year-old emperor of Punjab, Maharaja Duleep Singh, and the Colonial and Indian Exhibition (1886), where artefacts, archaeological and anthropological exhibits from the British Empire, with a prime focus on India (Arnold, 2011, pp. 75-89).

While richly crafted Indian artworks stood out at the Crystal Palace, the colony ruled visual passions at the Colonial and Indian Exhibition, whose Indian pavilions representing Oudh, the Bombay, Madras and Bengal Presidencies, North-West Frontier and Central Provinces, Punjab, Kashmir, and many other regions of the Raj were meant to visually transport spectators "from one part of India to another" in the confines of central London, without them having to bother travelling all the way to the colony (Colonial and Indian Exhibition Off. Cat. 2, 1886). That the latter was organized within a year of the founding of the Indian National Congress had widespread implications for how Indians were and aspired to be represented to Western eyes and in turn represent imperial London to Indians back home-how London would henceforward visually consume the Raj and how India would come to consume London in travelogues.

This paper draws a new hermeneutic framework in which to read Indian accounts of London between 1870 and 1900 -about one and half decades on either side of an axis that came to be drawn by the founding of the Indian National Congress. Taking critiques of Orientalism as a model to understand counter-ethnographic discourses written about the imperial capital by Indian travellers like Pothum Janakummah Ragaviah, Trailokyanath Mukharji, Lala Baijnath Behramji Malabari, G.P. Pillai and T.B. Pandian, I argue that Victorian London lurked as mythological and archetypal entity in the Indian imagination of the Occident.

The British imperial project was marked by the duality of representing and exhibiting India to London's eyes while delegitimizing notions of the existence of an Indian nation before the advent of the British in the colony. To mark their own space, therefore, Indian travellers to 
London resorted to a typographical imagination. They saw its imperial power centres and institutions as the models for reimagining an autonomous geography for the colonized. In the phenomenology of metropolitan English life-its atmosphere, audible imagery, sights and sounds-Indian travelogues could unburden the ongoing traumas of colonization back home and usher a new hermeneutics of Indian modernity through a literary proficiency in London life.

If, as Dipesh Chakrabarty has argued, provincializing Europe was one of the key experiences of urban political modernity in India (Chakrabarty, 2000, p. 6), provincializing London for Indian readers was not just a literary enterprise but also a political strategy to carve a psychogeographical space for a new kind of cultural mobility, and the autonomy of representing imperialism over and above being represented by the imperialist. The typographical imagination in which London, especially Victorian London since the 1870 , was represented to Indians by Indians occurred more in the psychogeographical interstices of texts and their typography than on the geographical contours of the imperial metropolis. These interrogations of imperial power refashioned popular districts and areas of London-Kensingtons, Bloomsburys, The Strands and the Belgravias-as, what I attempt to summon in the neologism, "Typogravia."

\section{An Experiment with Typography}

In 1888, London was a home to a homesick law student, Mohandas K. Gandhi, lonely and haunted by his mother's love. In The Story of My Experiments with Truth (1927), where London occupied a prominent place, Gandhi writes that he wanted to play the perfect English gentleman but also went about seeking vegetarian restaurants around Holborn and Bloomsbury(Gandhi, 1983, pp. 3556), armed with a copy of Henry Stephen Salt's A Plea for Vegetarianism, published two years ago by the Manchester Vegetarian Society. This clearly indicates a threshold in the Indian imagination of London, on one side of which the colonized subject implemented ways of performing the assimilation of an Indian identity into an English ego, and on the other reclaiming an Indian cultural identity through experiments of knowing London more intimately.

The city of shops, shopkeepers, spectacles and theatres, as it appeared both to Charles Dickens and Keshub Chandra Sen (Knight,1841, p. 37; Sen, 1938, p. 481), was taken beyond the limits of Victorian sovereignty towards an infinitude of interpretation in the Indian mind, where every new sign and turn of phrase concerning London became "in turn written matter for further discourse" (Foucault, 2002, p. 46). Not only was London thrown open to new interpretations, like the Bible had been with the coming of the St. James' version in the seventeenth-century, but also that inhabiting this new Typogravia was a therapeutic and decolonizing gesture for and by the Indian psyche to convalesce in a safe space, while battling against asymmetrical imperial power equations on visual, political and administrative scales. It was a typographical experiment in the process of knowing London-charting therein a home for those grown homesick in London or back in India for an elusive home-embracing its nuances as best as could be retained in the colonized memory, and as best as could be inscribed and reinscribed for personal and public consumption in the colony.

Victorian London was sustained as a centre for global capital, culture, light and learning on an unprecedented scale (Williams, 1973, p. 229). Much of that was assured by colonially reproducing India as a vassal state with an economically and intellectually inferior native population, together with a forcible devaluation of Indian currency in comparison to global sterling standards. In the 189os, Indian markets were turned into a hostage for a major bulk of British textiles and locomotives, and the subcontinent itself into a massive playground for railway 
experiments (Chatterjee, 2018, pp. 70-130). The great economic drain from India to Britain helped, despite millions of deaths due to man-made famines in the colony, helped imperialism preserve an "uneven historical geography of capitalism" (Goswami, 2004, p. 70-72). It is therefore imperative to see Typogravia as a challenge not just to the cultural registers of urban spatiality in which Indians saw themselves and their colonial masters but also, as Julie Codell observes, in a "guest discourse" (2007, p. 174), where the colonized traveller could reverse the political and economic domination heralded in the late-nineteenth-century while enjoying the hospitality of the colonizing race in London.

Defined as "counterflows to colonialism" by Michael H. Fisher (2006), Indian immigrants and visitors had live and died in London since before Shakespeare, although their number peaked especially in Victorian times, touching about 40,000 (Fisher, 2007, pp. 304-305). Eighteenthcentury travellers to London, Joseph Emin, Ihtishamuddin, Abu Taleb Khan, Hanumant Rao and Sake Dean Mahomet, all published travelogues containing accounts of the city, but the most crucial turn in the history of Indians writing about London came with the expansion of print culture, around the mid-nineteenth-century.

In The Gutenberg Galaxy (1962), Marshall McLuhan historicized the making of the typographic man in Europe, arguing that inventions in printing and typography during the Renaissance fostered mechanization of artistic reproduction and applied knowledge over medieval pluralism. Technological expansion, sociopolitical metamorphosis and the expansion of geographical frontiers of civilization became "the archetypal norm of social life," in which the new typographical imagination transformed language and linguistic expressions into portable and privately consumed commodities (1962, p. 155). Victorian India too witnessed a typographical revolution when English studies was invented in and for the colony to further the British civilizational mission through the institutionalization of English literary since Shakespeare (Vishwanathan, 2015, pp.7-8; 45-46; 160-61).

London lurked in that new typographical imagination as a portable commodity. The imperial capital that came to be typographically imagined in the travelogues to follow, was as much shaped in the Indian memory by elitist neighborhoods like Belgravia and the rank poverty of the East End. They were imaginatively coalescing into a grove or gravia of experiences, within a geographical terrain reinterpreted as psychogeographical text, or a Typogravia. In this paper I discuss two kinds of typographical experiments-pictograms and audiograms-that Indian travelogues deployed to territorialize London for the sensorium of Indian readers.

Building on observations that Victorian London was a site for the development of the aesthetic Indian subject and a reconfiguration of imperial power equations between Britain and the colony (Nayar, 2012; Burton, 1996), Typogravia emerges as a phenomenology of the psychic spaces or extensions of London in the Indian imagination. It was a portable therapeutic commodity for the recuperation of contradictory forces of the global culture and capital of imperialism, which on the one hand made Shakespeare a symbol of Indian national culture in colonial India for the likes of Nirad C. Chaudhuri (1968, p. 190), and on the other, as Bipin Chandra Pal contended, controlled the economy of the Empire that disallowed for the entry of German capital into India in the same terms that it entered Great Britain or European literary and philosophical ideas entered India (1920, p. 83).

Be that as it may, the administrative, historical and cultural centres of Westminster and Bloomsbury, Knightsbridge and Kensington or Mayfair and Marylebone, or the names of the royalty, like Victoria, Gladstone, Roberts, Kitchener, Buller, Methuen, Rosebery, Burke and 
Hastings lingered in the Indian imagination like a spell that could manufacture an entire city built on the music of the memories of colonization.

\section{English Atmosphere in Indian Archetype}

Pictograms and audiograms of London in Indian travelogues operated as archetypes for a sensory liberation of the colonized psyche. An archetype, or a representative pattern of psychic experiences, operates in a subliminal space and resonates in the unconscious memories and dreams of a class or community of people. In the pictograms and audiograms recorded in this paper, we see visual and musical patterns which get reinscribed and reaffirmed by successive travelogues, in an attempt to hammer a dreamland into existence, "essentially an unconscious content that is altered by becoming conscious and by being perceived," as Carl Jung would explain (2014, II,p. 5).

Musical pictograms for Malabari had a special place in his book Indian Eye on English Life (1895), and ethereal at that, carrying the "inarticulate eloquence of the bells" at St. Paul's Cathedral resonating with the "virgin voices of the choir" calling forth his soul (Malabari, 1895, p. 98). Malabari arrived in London in 1890, the year that Gandhi returned to India as a barrister, therefore his travelogue operates from the very centre of the discourse of the anticolonial freedom struggle.

In T.B. Pandian's English Pictures from an Indian Camera (1897) musical experience at the Albert Memorial Hall comes as a fulfillment of Malabari's incomplete audiogram. "I was carried out of myself and away from Earth," wrote the mesmerized traveller, "fancying myself listening to a glorious anthem of praise sung by some tuneful celestial choir. It seemed to me so like the music of another sphere that I half imagined myself in Heaven itself" (Pandian, 1897, p.29). The grandiloquence of Westminster's or St. Paul's bells stirs echoes in the industrial walks of London as a distant but healing landscape where, as Malabari noted, "I sit entranced, watching the divergent forces. The noise and bustle-the everlasting clang of feet, the whistling of engines and smoking of chimneys are music to my ear" (1897, p. 192).

Pandian validated the audible imagery of London streets, conveying the colonial mind to a utopian setting whose underlings musically hawked their freshly harvested or packaged produce, orchestrating "a decidedly seductive sort of music in such common street calls as 'Cherries ripe,' Oranges, fresh oranges,' 'Milk, ho,' 'Hot cross-buns, one a penny, two a penny, hot-cross buns,' and scores of others, rung out in many cases by sweet girl-voices to be heard daily crying out up and down the leading thoroughfares of the great metropolis" (1897, p.45). If the cacophony of hawkers, omnibuses, railway stations, policemen and traffic characterized London's streets, the interiors of average middle-class English homes flaunted modish amenities, usually revolving around a piano whose music commanded many an Indian ear, and eye. The narrow corridors of corner houses, curtained doorways, carpeted morning parlors and cushioned lounges, bentwood armchairs and foreign curios, and indeed the piano, that Pandian walks us past, sum up the allurements for the reader. Even working class homes are not far behind: "A few neat ornaments stand on the mantel-shelf, and in addition to these there may, perhaps, be a teapoy or two and even a neat upright or cottage piano" (1897, p.7; 17).

There was music also in the courtesies of London that Pothum Janakummah Ragaviah-the first Indian woman to write a travelogue of her visit to Europe-drew on, in her book Pictures of England (1876). An almost audible pictogram from family life in Victorian London is seen in an 
English lady pianist cheering "the family circle and the visitors with her music, while a gentleman who understands the same, assists the lady by showing the pages of the music-book." Listening to the organ recital and psalms at Westminster Abbey, not unlike Malabari's visceral experience, Ragaviah felt as if a "chillness crept over my whole frame" (Ragaviah, 1876, p. 56; 75).

Affirmations of Victorian gaiety in Indian travelogues was a strategy to reaffirm the indubitable position of the travelling self and its solid informational grasp over the clockwork movements of the city. "What strikes an Asiatic most, on getting out at Victoria Station," quipped Malabari as a quasi-ethnographer, "is the noise and bustle around him. Every man and womanone might say every animal, and even some of the inanimate objects-seem to be full of life" (Malabari, 1895, p.27).

Malabari's pictography closely followed the routes of Lala Baijnath, whose book, England and India (1893), launches a relentless nomenclatural and pictographic experiment. The typographical experiment of the Indian traveller enlivens the sensorium of the colonized subject, where the typeface of the text is animated by the terrain of London.

From Regent Street is all easy turn through Oxford Street which crosses it. This street is one of the most continuous streets of this great city. It is full of shops of all descriptions and houses suited for persons of all classes. One end of it leads to Notting Hill and the other to Holborn and the City ... The Holborn side of Oxford Street leads to Cheapside at the end of which are the Royal Exchange, the Bank of England and the Mansion House. From Cheapside one can easily go into Fleet Street and the Strand, which are- not only full of shops, but also contain most of the leading publishing houses and newspaper offices ... From Charing Cross to Whitehall is a very easy drive as the rush of carriages is not large enough to obstruct one's progress. Here are the various public offices of the Ministry, the Horse Guards, the Houses of Parliament, and the India Office (called by the policemen and the cabby Indiar Office). I shall not describe the Houses of Parliament or Westminster Abbey for the present, but cross Westminster Bridge ... A more circuitous trip through Kensington brings the stranger to Hyde Park, while a second trip leads him to Victoria Station and thence to London Bridge ... Let us go towards Bayswater. I shall not enter Hyde Park now, as I wish to do so on my way back. I should like to see my Indian friends first. Most of them live in Bayswater, which has been nick-named Asia Minor, because almost all the Asiatics who visit London patronize the lodging-houses to be met with in that locality (Baijnath, 1893, pp. 27-29).

Baijnath, like many other Indian travellers, took readers on a journey across London and into the reservoirs of creating a new poetics of its spaces where the colonized psyche could find its oneiric shelter; like Europe had daydreamed the Orient into existence, London was willed into Typogravia by this new Occidentalist canon. The bridge-crossing that Baijnath takes us on is symbolic, as it would continue to operate as an archetypal threshold in the Indian imagination, even as late as Aditya Chopra's film, Dilwale Dulhania Le Jayenge (1995), where the Indian migrant Thakur Baldev Singh crosses the Westminster Bridge on his way to work, every day. Besides other instances of similar bridge-crossings, Ragaviah's pictographic train journey en route to the Waterloo Station marks a symbolic threshold for the initiation of the colonial subject into a freer world, usually signified in these travelogues by the dazzling lights of the city. She writes, "We crossed several bridges, and directing my view towards the innumerable turrets and high houses, the whole town seemed to be in a blaze, the cause being attributable to gas-lights with which the streets are lighted" (Ragaviah, 1876, pp.46).

Besides familiarizing readers with the popular spots of London, Typogravia laid down the routes whence Indian readers-and subsequent travellers-could find a homely metropolis as opposed to the dread of the gloomy and Gothic spaces that the Victorian or Dickensian canon was so characteristic of. It also ushered a new hermeneutics of London as the colonial text, 
experienced sensually, owing to the atmospheric realism attempted in most travelogues, inviting the mobility of the reader in the person of the tourist.

For Gaston Bachelard, author of The Poetics of Space (1969), the power of daydreaming about a space liberates its geography from its surroundings and historical specificities; it subsequently "floats and soars, immense, in the free atmosphere of a great poem" (Bachelard, 1969, p. 69). London was opened-like Bachelard would have the opening of a casket-within an atmosphere of novelty and surprise, as imagination sharpened the senses into "instantaneousness" (Bachelard, 1969, pp.85-87). To enable that effect, Barrister G.P. Pillai, who visited London in 1897, marked his travelogue, Through Indian Spectacles (1897), with an experiment conducted from his hotel room, where he himself, as a reader would, imagined the audible atmosphere of London, not while walking in the city but in reminiscing - the quaint acoustics horses trotting on cobbled streets, footsteps and voices clamouring towards railway carriages, the hooting and rattling of railway engines-those audiograms that contradict Pillai's own message: "You may read of London all your life, but you will never know what it is like, unless you see it" (Pillai, 1897,p. 160).

More than a spoiler for the reader, Pillai lays out ways of seeing and hearing London from within, beginning with the interiors: the cozy furniture, window panes, papered walls, the clock on the mantelpiece, the bell in the corner and the ambient sound of the traffic outside. The unmistakable simple present tense and the pronoun "you," in Pillai's prose- "these be strange characters in a strange land and it takes some time before you become familiar"-conjures the reader himself as a companion on London's streets, while the city is broken down into imaginative snippets and types, to be imagined in typefaces.

Trailokyanath Mukharji, who was in London as a supervisor at the Colonial and Indian Exhibition, and a guest at Max Muller's Oxford residence, oscillated between exterior and interior spaces of the metropolis with perfect ease. His description of a London morning, extricating itself out of the fog, is reminiscent of William Wordsworth's sonnet composed upon the Westminster Bridge in 1802, and somewhat anticipates Claude Monet's paintings on the London fog from the turn of the century. Mukharji's personification of the dawn as a pubescent girl camouflages the strategy of the travelogue. Here the travel guide assumes the avatar of a child to walk and enlighten the reader in the imperial capital during its most unguarded hours.

... little Twilight rose from her bed, and opened the shutters of heaven close by the Docks and Arsenals of Woolwich. Putting on her pretty gray apron, she gently tripped into the London world, and began to sweep the muggy mist that hung heavy all around. She swept the Thames, from Greenwich of Observatory fame, where begin the lines that intersect the hemispheres from pole to pole, to verdant Kew where she peeped through the glass roof to greet the feathery palm, happy in its delusion, to have taken the reeking clime within for its native Africa. She brushed the fog off the tall Monument, off the tower at Westminster where Big Ben tells the time, off housetops under which lay asleep tired London, and with the aid of the morning breeze shook the summer foliage in the Parks and drove away the gloom that hid among them for refuge. Thus from half past two to half past three, Morning Twilight busied herself to sweep, brush and dust the world and to make everything neat and tidy. When behold there was glory in the East! A jet of gaseous gold was suddenly spurted from the heavens, and all the tall chimneys of the town anxiously raised their heads to catch the bright effulgence. It rested for a while like a golden cap on the heads of these high minarets of the western world, and then unfolded itself and slid down as a brocade mantle covering the slate roofs, the balcony rails and finally the deserted roads below (Mukharji, 1889, p. 201).

The inner dialectic between East and West, disguised in the games of a little child and elements of nature, serves as a wish-fulfilment of finding London as a virgin territory which can 
be territorialized as a typographic experiment, which in turn marks the many negotiations of colonial identity and literacy that the Indian traveller was expected to make in heart of Empire. The itinerary of Indian travellers usually followed the routes suggested by the tourist brochures of the day that "nearly always included stops at Westminster Abbey, the Houses of Parliament, Whitehall, Trafalgar Square, Fleet Street and St. Paul's" (Burton, 1996,p. 133). It was almost customary to drop those names to whet the nomenclatural appetite of the reader back home-a custom that soon graduated to becoming the symphony for readers to imagine the grandeur of London's churches and cathedrals. Cataloguing their honourable and memorable names was a "form of textual control" over the magnitude of English modernity and what Indians could derive therefrom (Pandian, 1897, p. 32; Ram, 1893,p. 45; Nayar, 2012, p. 38).

Music being a common trope for transporting readers into the typographical landscape, Mukharji used the pictogram earlier deployed by Ragaviah, as it were, for the "embellishment" of the sitting room in his reader's imagination: "the sound of a piano may be reaching your ears from the Drawing Room on the other side, where a young lady in her evening-dress, looking like the presiding angel of all celestial flowers, is engaged in bringing down the sweet harmony of heaven into this mundane world" (Ragaviah, 1876, p. 218). Nayar calls these expressions of wonder an "informed enchantment," meant to train the reader to experience wonder textually and excavate deeper into English culture, perhaps to secretly carve out an Indian niche therein. "The modernity embodied in these works is cosmopolitan in which the first signs of a global Indian are visible in their easy mobility across England's cultural geography recorded in these texts" (Nayar, 2011, p. 40; 50).

Those like Malabari saw London as a text, "perforated from end to end" with Underground trains and train stations having amassed an unknown city beneath the somewhat known city above (45). "Suddenly, you grow nervous-you are told, all is hollow beneath your feet," we hear in Pillai's theatrical interlude, preparing us for instantaneity and the revelation of an interior London. "Beneath the pavements are storerooms," he adds, "through the sky-lights you are sometimes able to see what is within. You see a railway station. You enter and you feel you are going underground. You get into a train and it steams out. Now in light, now in darkness, less in light and more in darkness, you travel" (Malabari, 1895, pp. 159-60). Like the text of the pages of Pillai's book-alternating black and white forms-London is thrown open as a psychic possession, where colonial readers were "free to wander its avenues and hence to claim its grandeur and its power as their own” (Burton, 1996, p. 133).

From Ragaviah's camera to Baijnath's pictography, from Mukharji's awakening senses to Malabari's wandering eyes, from to Pillai's spectacles to Pandian's audible portraits, London scenes come full circle in the subliminal consciousness of the Indian reader. They inscribe a space for reveries where reading and writing about the imperial capital was akin to free association-the fulfilment of a deep-seated wish for an independent geography. Inhabiting Typogravia was the dream symbolism for India's independence. Typogravia was an archetype that, as Carl Jung would have, represented a collective event boring deep beneath individual psychologies into the ocean of a collective psyche. "It is a power that fascinates people from within," wrote Jung, "it is the collective unconscious which is activated, it is an archetype which is common to them all that has come to life" (Jung, 2014, II, pp.163-64). In becoming an archetypal force, Typogravia enabled Indians to reimagine London within a framework of reproducibly recognizable sounds, sights and other sensual networks where the whole race of English-educated Indians could move as a crowd without the anxiety of being considered an unwelcome alien, or the anxiety of being gazed at. 


\section{Kaleidoscapes of London}

In Modernity at Large (1996), one of the relations that Arjun Appadurai identifies in global cultural interactions in the post-imperial world is "ethno-scapes," explaining that the suffix "scape" suggests neither a leisurely and elitist escape from the interests of ordinary people, nor "objectively given relations that look the same from every angle of vision but, rather, that they are deeply perspectival constructs, inflected by the historical, linguistic, and political situatedness of different sorts of actors" (Appadurai, 1996, p. 33).

Adding that all-important suffix to the kaleidoscopic transformations that London has seen-demographically, culturally and morphologically-in places like Southall which have a great concentration of South Asian peoples, Noha Nasser (2004) calls for global cities like London to be seen as an amalgamation of "kaleido-scapes" which reflect not only the aspirations of a postcolonial South Asian population in an English borough but also the aspirations of London itself. In other words, the ethno-scapes and kaleido-scapes that one finds in contemporary voices of South Asian origin writing on, from and around London (Monica Ali, Kamila Shamsie, Hanif Kureishi, Daljit Nagra, and many others)are perspectival glimpses of London, which sooner or later go on to affect the brick and mortar dimensions of the city.

With over half a million British Indians and a million British South Asian people in London today, and with Brick Lane, Wembley, Hillingdon, Tooting and East Ham abounding in Indian, Pakistani and Bangladeshi vendors, restauranteurs, proprietors, travel agents the ethnoscapes and kaleido-scapes of nineteenth-century Indian travelogues to the city acquire a new geopolitical significance. In training the Indian (what is today's South Asian) sensibility in inhabiting London in psychogeographical and atmospheric ways, they had not only played a decolonizing and empowering role for the colonized traveller and reader caught in a web of imperial relations.

In creating a Typogravia, they also cradled the culture of a postcolonial and global London which erstwhile colonizers would share with people from the erstwhile colonized ethnicities. Typogravia was, therefore, not merely a local intervention by a group of Indian travellers in the heart of Albion. It was a training in the cultures, manners and phenomena of the Occident with which erstwhile Orientals, in assuming a global postcolonial avatar of migrants to Britain following the 1950s, would transform Britain from within.

\section{Works Cited}

Appadurai, A. (1996). Modernity at large. Minneapolis \& London: University of Minnesota Press

Arnold, J. (2011).Victorian jewelry, identity, and the novel. Farnham \& Burlington: Ashgate

Bachelard, G. (1994). The poetics of space, trans. Maria Jolas. Boston: Beacon Press

Baijnath, L. (1893). England and India: Being impressions of persons and things, English and Indian, and brief notes of visits to France, Switzerland, Italy and Ceylon. Bombay: Jahangir B. Karani

Barrows, A. (2011). The cosmic time of empire: modern Britain and world literature. Berkeley \& London: University of California Press

Burton, A. (1998). At the heart of the empire: Indians and the colonial encounter in late-Victorian Britain.Berkeley \& Oxford: University of California Press 
- (1996). Making a spectacle of empire: Indian travellers in fin-de-siècle London. History Workshop Journal,42,126-46.

Chakrabarty, D. (200o).Provincializing Europe: Postcolonial thought and historical difference. Princeton: Princeton University Press

Chatterjee, A.K. (2018).The great Indian railways. New Delhi \& London: Bloomsbury

Chaudhuri, N.C. (1968).The autobiography of an unknown Indian. Berkeley \& Los Angeles: University of California Press

Chopra, Y. (Producer), \& Chopra, A. (Director). (1995). Dilwale Dulhania Le Jayenge [Motion Picture]. India: Yash Raj Films

Codell, J. (2007).Reversing the grand tour: Guest discourse in Indian travel narratives.Huntington Library Quarterly, 70(1), 173-189

Colonial and Indian Exhibition 1886 Official Catalogue (1886). London

Fisher, M.H. (2006).Counterflows to colonialism: Indian travellers and settlers in Britain, 1600-1857.New Delhi: Permanent Black

- (2007). Excluding and including "natives of India": Early-nineteenth-century British-Indian race relations in Britain. Comparative Studies of South Asia, Africa and the Middle East,27(2), 303-314

Foucault, M. (2002). The order of things: An archaeology of human sciences. New York \& London: Routledge

Gandhi, M.K. (1983). Autobiography: The story of my experiments with truth. New Delhi: Courier Corporation

Goswami, M. (2004). Producing India. New Delhi: Permanent Black

Greenblatt, S. (1991). Marvelous possessions: Wonders of the new world. University of Chicago Press

Jung, C.G. (2014). Symbolic life, trans. R.C. Hull. East Sussex: Routledge

-(2014). The archetypes and the collective unconscious, trans. R.C. Hull. East Sussex: Routledge

Kiernan, V.G. (1969). The lords of human kind. Boston: Little, Brown \& Co.

Knight, C. (Ed.) (1841). London, Vol. 9. London: Charles Knight

Lahiri, S. (2013). Indians in Britain: Anglo-Indian encounters, race and identity, 1880-1930. Abingdon \& New York: Routledge

Malabari, B. (1895).The Indian eye on English life: Or rambles of a pilgrim reformer. London: Apollo Printing Works

McClintock, A. (1995). Imperial leather: race, gender and sexuality in the colonial contest. New York \& London: Routledge

McLuhan, M. (1962). The Gutenberg galaxy: The making of typographic man. Toronto: University of Toronto Press

Mukharji, T. (1889). A visit to Europe. Calcutta: W. Newman

Nasser, N. (2004). Southall's kaleido-scape: A study in the challenging morphology of a west London suburb. Built Environment (1978-),30(1), 76-103.

Nasta, S. (Ed.), (2013). India in Britain: South Asian networks and connections, 1858-1950. Basingstoke: Palgrave Macmillan

Nayar, P.K. (2012). Colonial subjects and aesthetic understanding: Indian travel literature about England, 1870-1900.South Asian Review, 33(1),31-52 
Pal, B.C. (1920). The new economic menace to India. Calcutta: Ganesh \& Co.

Pandian, T.B. (1897). England to an Indian eye, or, English pictures from an Indian camera. London: Elliot Stock

Pillai, G.P. (1897). London and Paris through Indian spectacles. Madras: Vaijayanti Press

Ram, J. (1893). My trip to Europe. Lahore: Mufid-I-Am Press

Ragaviah, P.J. (1876). Pictures of England: Descriptive of her visit to Europe. Madras: Gantz Bros.

Roy, A.K. (1905). Impressions of England. Calcutta: New Arya Mission Press

Said, E. (1979). Orientalism. New York \& London: Vintage

Sen, K.C. (1938). Keshub Chunder Sen in England: Diary, sermons, addresses E epistles. Calcutta: Navavidhan Publication Committee

Sen, S. (2005). Travels to Europe: Self and other in Bengali travel narratives, 1870-1910. Hyderabad: Orient Longman

The Dispatches of Field Marshal the Duke of Wellington (1837).The Quarterly Review, 58 (pp. 82-107). London: John Murray

Vishwanathan, G. (2015). Masks of conquest: Literary study and British rule in India. New York: Columbia University Press

Visram, R. (2002). Asians in Britain: 400 years of history. London: Pluto Press

Visvanathan, S. (1997). A carnival for science: Essays on science, technology and development. Calcutta \& Mumbai

Williams, R. (1973). The country and the city. New York: Oxford University Press

Arup K. Chatterjee is Associate Professor of English, at OP Jindal Global University. He is the Founder Chief Editor of Coldnoon: International Journal of Travel Writing\& Travelling Cultures. He is the author of The Purveyors of Destiny: A Cultural Biography of the Indian Railways (2017), The Great Indian Railways (2018) and Indians in London: From the Birth of the East India Company to Independent India. He has contributed numerous articles on history, literature, culture and politics, to magazines such as The Hindu, Hindustan Times, The Conversation, Scroll, The Wire, DailyO and Huffington Post, India Today, Open, The Caravan, apart from contributing to Coldnoon. He has been or is about to be interviewed in All India Radio, The Missing Slate, Writers in Conversation, SBS Radio Australia, The Quint and BBC India. 